summarizes the percentage retention of ascorbic acid in the various stages of the drying process; it will be seen that the use of sulphite in the scalding liquor results in improved retention.

I wish to thank the Directors of J. Lyons and Co. for permission to make this communication.

\title{
REFERENCES
}

Adam, W. B. (194I). Ann. Rep. Campden Res. Sta. 194r.

Allen, R. J. L., Barker, J. \& Mapson, L. W. (1943). F. Soc. chem. Ind., Lond., 62, $145 \cdot$

\section{The Preservation of Fruit-juice Products, with Special Reference to Nutritional Value}

\author{
By Vernon L. S. Charley, H. W. Carter and Co. Ltd., Bristol
}

The fruit-juice products with which this paper is concerned are all liquids, but their preservation is effected by various means. Some straight juices, e.g. apple and grape, can be filtered to a completely sterile condition; squashes which retain a proportion of the fruit tissue cannot be filtered, and must be preserved by other methods; some juices are particularly vulnerable to flavour alteration by heat and consequently pasteurization is not acceptable. In a review of this nature only the salient feature of each process can be given. As the preceding papers by Money (1947) and Baker (1947) have given considerable prominence to the chemical method which is common to the preservation of both fruit and vegetables and their juices, this paper will concentrate more especially on other widely used methods.

\section{Nature of changes occurring in fruit juices}

The changes which most generally occur in fruit juices in the unpreserved state fall into the following categories: ( $\mathrm{I}$ ) Yeast and bacterial action causing fermentation of normal or abnormal type, or acetification; (2) enzyme action, i.e. decomposition of pectin by naturally occurring enzymes which causes unsightly deposits; (3) changes due to interaction of many of the naturally occurring chemicals in the juice, and to some extent due to the presence of oxygen, which oxidizes flavouring compounds, ascorbic acid and the sulphur dioxide often added as a preservative.

The preservation of these products must take account of flavour, for this is one of the most important factors determining the palatability of a food product. Generally speaking, the factors which favour the retention of the true fresh-fruit flavours are those that tend to ascorbic acid retention.

Preservation of fruit juice products may be examined in three sections. Fruit, being a seasonable and perishable commodity, has to be processed during a restricted season and stored, generally in bulk, until needed for bottling or canning. This involves 
questions of preservation of juice in bulk. Next, the product must be filled into the container in which it will finally be purchased, and must be preserved for what is known as its shelf life. Lastly, the contents of the opened bottle or can must remain stable for a reasonable period, which will vary with the product. Thus, a small bottle of apple juice would undoubtedly be consumed at one sitting. On the other hand, a black-currant syrup used as a vitamin $\mathrm{C}$ supplement would be used at a rate of I fluid oz./day, the bottle taking I4 days to be emptied. With a guaranteed ascorbic acid content in the syrup, it is essential to ensure that the last dose of syrup contains its full declared vitamin potency. Many products that could safely be maintained sterile by a pasteurization process alone have to be doubly preserved by the addition of sulphur dioxide, the latter being added both to maintain the ascorbic acid content during the shelf life and to inhibit any living organisms that fall into the bottle during the period of its use.

\section{Types of liquid fruit products}

The various types of products which have been selected for mention in this paper are briefly enumerated below:

Straight fruit juices: apple, grape (clear), tomato, pineapple, orange (cloudy).

Sweetened juices: juices from sharper fruit which need some addition of sugar to obtain a correct ratio of soluble solids to acidity: e.g. loganberry, raspberry, grapefruit.

Fruit syrups: pure juice and solid cane sugar.

Squashes: products made from citrus juices; these contain $25-30 \%$ of juice and some natural fruit tissue.

Concentrated syrups and juices: e.g. orange juice for welfare distribution by the Ministry of Food, and rose-hip syrup.

Some analyses of these products are given in Table $\mathrm{I}$.

\section{Method of preservation}

The chief methods employed to preserve fruit juices will now be considered.

\section{High-pressure storage and sterile filtration}

The first part of this process originated in Switzerland (Boehi storage) and the second part in Germany (Seitz filtration).

The bulk preservation of juices intended for marketing in a clear condition can be effected by storage at $15^{\circ}$ under $\mathrm{CO}_{2}$ at a pressure of $120 \mathrm{lb}$./sq.in. It is essential to maintain a concentration of $\mathrm{CO}_{2}$ of $10 \mathrm{~g}$./1. of juice throughout the bulk; with this, fermentation is completely inhibited and many of the flavour changes in juices are retarded. The ascorbic acid of black-currant juice is well retained, but the vitamin C of apple juice has generally disappeared before the juice can be pumped to the tank.

The complementary process is the Seitz cold filtration and bottling method. Completely aseptic in its operation, this process enables a juice to be bottled without the application of heat, and provides products with fine flavours, truly reminiscent of the fresh fruits. The processes of Boehi and Seitz do not affect enzymes, and loss of 
ascorbic acid may occur if juices high in vitamin $\mathrm{C}$ are bottled by this method. The process is suitable for brilliant juices only and has no usefulness for citrus or tomato products.

\section{Table I. Average analysis of liquid fruit products}

\begin{tabular}{|c|c|c|c|c|}
\hline & $\begin{array}{c}\text { Total sugars } \\
\text { (as invert sugar) } \\
(\%)^{*}\end{array}$ & $\begin{array}{c}\text { Acidity } \\
\text { (as citric acid) } \\
(\%)^{*}\end{array}$ & $\begin{array}{l}\text { Ascorbic acid } \\
\text { (mg./100 ml.)* }\end{array}$ & $\begin{array}{l}\text { Sulphur } \\
\text { dioxide } \\
\text { allowed } \\
\text { (p.p.m.) }\end{array}$ \\
\hline \multicolumn{5}{|l|}{ Straight juices: } \\
\hline Black currant & $5 \cdot 8-13 \cdot 0$ & $3 \cdot 4-5 \cdot 5$ & $90-360$ & 70 \\
\hline Red currant & $6 \cdot 2$ & $2 \cdot 0-2 \cdot 8$ & $35-50$ & 70 \\
\hline Blackberry & $5 \cdot 4-6 \cdot 0$ & $0 \cdot 9-2 \cdot 2$ & Trace & 70 \\
\hline Strawberry & $3 \cdot 6$ & $0 \cdot 6-1 \cdot 1$ & $30-55$ & 70 \\
\hline Raspberry & $7 \cdot 0-7 \cdot 6$ & $1 \cdot 0-2 \cdot 4$ & $20-30$ & 70 \\
\hline Loganberry & 6.5 & $1 \cdot 9-3 \cdot 0$ & $10-20$ & 70 \\
\hline Gooseberry & - & $2 \cdot 0$ & $15-27$ & 70 \\
\hline Grape & $13 \cdot 8-19 \cdot 7$ & $0.5-1.6$ & $1-3$ & 70 \\
\hline Cherry & $9 \cdot 1$ & $0.5-1.8$ & $2-5$ & 70 \\
\hline Plum & $6 \cdot 0-18.0$ & $0 \cdot 4-r \cdot 5$ & $2-15$ & 70 \\
\hline Tomato & $3 \cdot 1-4 \cdot 0$ & 0.4 & I6-33 & 70 \\
\hline Apple & $8 \cdot 0-12 \cdot 0$ & $0 \cdot I-1 \cdot 2 \dagger$ & $2-34$ & Nil \\
\hline Passion fruit & II 5 & $2 \cdot 0-2 \cdot 6$ & $10-30$ & 70 \\
\hline Tangerine & $\ldots$ & $I \cdot 26$ & $18-37$ & 70 \\
\hline Pineapple & $10.3-13.0$ & $0 \cdot 7-\mathrm{I} \cdot 0$ & 21 & 70 \\
\hline Orange & $4 \cdot 5-14.0$ & $0 \cdot 4-1 \cdot 6$ & $30-65$ & 70 \\
\hline Lemon & $I \cdot I-3 \cdot 6$ & $4 \cdot 0-8 \cdot 0$ & $3^{0--55}$ & 70 \\
\hline Lime & 0.3 & $7 \cdot 4-7 \cdot 8$ & $8-6 z$ & 70 \\
\hline Grapefruit & $3 \cdot 4-9 \cdot 7$ & $0 \cdot 7-2 \cdot 6$ & $37-50$ & 70 \\
\hline \multicolumn{5}{|l|}{ Sweetened juices: } \\
\hline Loganberry & 20 & $1 \cdot 5$ & - & 70 \\
\hline Grapefruit & 20 & $I \cdot 5$ & 一 & 70 \\
\hline \multicolumn{5}{|l|}{ Syrups: } \\
\hline Strawberry & 55 & $I \cdot I$ & - & $35^{\circ}$ \\
\hline Loganberry & 55 & $I \cdot 2$ & - & $35^{\circ}$ \\
\hline Black currant & 55 & $2 \cdot 0$ & 60 & $35^{\circ}$ \\
\hline \multicolumn{5}{|c|}{ Concentrated syrup: } \\
\hline Black currant & 53 & $8 \cdot 5$ & $35^{\circ}$ & $35^{\circ}$ \\
\hline \multicolumn{5}{|c|}{ Concentrated juices: } \\
\hline Apple & 57 & $5 \cdot 0 \dagger$ & - & $35^{\circ}$ \\
\hline Strawberry & 57 & 4.0 & 150 & 350 \\
\hline Loganberry & 28 & 17.0 & 125 & 350 \\
\hline Black currant & 40 & $16 \cdot 0$ & 700 & 350 \\
\hline \multicolumn{5}{|c|}{ Fruit squashes (pre-war): } \\
\hline Orange & $35-40$ & $1 \cdot 0$ & - & $35^{\circ}$ \\
\hline Lemon & $35-40$ & $2 \cdot 0$ & - & $35^{\circ}$ \\
\hline Grapefruit & $35-40$ & I.0 & - & 350 \\
\hline Lime & $35-40$ & $2 \cdot 0$ & - & $35^{\circ}$ \\
\hline
\end{tabular}

* Straight juices are calculated on a volume basis; for all other products the calculation is on a weight basis.

$\dagger$ As malic acid.

\section{Pasteurization}

It is comparatively easy to sterilize a fruit juice by boiling it as one does jam. The final product would, however, entirely lose its appeal owing to a heavy, cooked aroma and flavour. Pasteurization must therefore be applied in such a way that while 
satisfactory protection from microbial activity is secured, the flavour of the product does not deteriorate unduly. Probably no method of pasteurization widely employed to-day leaves the juice with precisely the same flavour as it possessed originally. The ideal temperature to meet these two conditions has to be found for each product. Pasteurization of any juice in a normal condition needs to be effected at a considerably higher temperature than if the juice is de-aerated or is carbonated to a pressure of $30 \mathrm{lb} . \mathrm{CO}_{2}$. The normal conditions for clear juices are pasteurization at $170^{\circ} \mathrm{F}$. for $30 \mathrm{~min}$., or flash pasteurization (high temperature-short time) at $185-190^{\circ} \mathrm{F}$. for $20 \mathrm{sec}$., followed by cooling to $160^{\circ} \mathrm{F}$. for bottling or canning and a further cooling to room temperature after $5 \mathrm{~min}$. in which the hot juice sterilizes the container. These temperatures are sufficient to inhibit enzyme activity. In the case of citrus juices in general, it is now the policy of processers to withdraw the fresh juice from the reamers and flash-pasteurize at once. In this way enzyme systems that destroy or reduce ascorbic acid or pectin in the juice are killed, and a sterile juice is obtained at the very start. In recent years flash-pasteurizing has been carried out along with an efficient de-aeration system designed to withdraw from the juice at least $90 \%$ of the original content of oxygen carried from the intercellular spaces of the fruit. Many claims have been made for the good effect of such de-aeration. Other conditions being similar, the removal of oxygen certainly aids retention of flavour, ascorbic acid and unoxidized sulphur dioxide.

Cloudy juices are pasteurized at $190-205^{\circ} \mathrm{F}$. for $10-60 \mathrm{sec}$, and cooled to a temperature of about $160^{\circ} \mathrm{F}$. for filling. The tendency for modern processing to increase the temperature and make a drastic reduction in time is shown by indications from the U.S.A. that the best conditions are heating to $225-240^{\circ} \mathrm{F}$. in $2 \mathrm{sec}$. and immediate cooling to $100^{\circ} \mathrm{F}$. for aseptic filling (Boyd \& Peterson, 1945).

Tomato juice introduces a unique problem of processing. In unsuitable weather conditions tomatoes are very perishable; they develop splits, and thus become vulnerable to moulds, which develop at astonishing rates. The fruit must be sorted and trimmed by hand, after which it is roughly chopped and the cores removed. The tissue is immediately scalded for $3 \mathrm{~min}$. in live steam and the juice removed in a screw expeller press. Pre-heating, de-aeration, a final heating to $180^{\circ} \mathrm{F}$., followed by canning or bottling is the normal sequence, and in many factories the canned or bottled juices are processed in boiling water for $15-40 \mathrm{~min}$. according to the size of the container.

One feature of interest in tomato juice is the presence of a particularly active pectin methoxylase which removes methoxyl groups from pectin with formation of methyl alcohol and pectic acid. Kertesz $\left(193^{8}\right)$ has shown that in the juice from ripe tomatoes the enzyme is so active that at $15^{\circ}$ the degradation of pectin is almost complete in 4 min. It is obvious that if a juice of homogeneous consistency is required with full viscosity from its pectin content, then 4 min. represents 'zero hour', and the enzymes must be inactivated before that time.

\section{Low-temperature storage}

Refrigeration is not of much use unless very low temperatures are attained. The juices are chilled to $34^{\circ} \mathrm{F}$, packed into containers and frozen solid at $0^{\circ} \mathrm{F}$. or below. 
Long term storage must be at $\mathrm{O}-10^{\circ} \mathrm{F}$. Retention of ascorbic acid in orange juice is almost perfect at these temperatures (Nelson \& Mottern, 1933), although Tressler \& Curran (1938) found that tomato juice suffered a loss of $80 \%$ of the vitamin in bottles with a large head-space.

As an example of the importance, under modern conditions, of appearance and flavour of foodstuffs, it is interesting to note that ascorbic acid is added in America to frozen fruit products (chiefly from apricots and peaches) merely to retain flavour and colour (Vitamin Division, Hoffmann-La Roche Inc., New Jersey, U.S.A., I946).

\section{Oligodynamic methods}

At one stage of the development of the fruit-juice industry, the oligodynamic method seemed likely to be of importance. Under ideal conditions, juices were said to be adequately preserved by minute quantities of silver. In the Katadyn process silver to the extent of 2 p.p.m. was passed into the juice by electrical means. The silver was reputed to be in an 'active' condition for several months, and to be capable of inhibiting the growth of adventitious airborne organisms gaining access to the juice after the container was opened. The Matzka process combined the use of silver at very low concentrations with a modified heat treatment. In some countries these processes are prohibited by the food laws.

\section{Chemical preservatives}

The general use of chemical preservatives in foodstuffs containing fruits and vegetables has been discussed in detail by Money (1947) and Baker (1947). The attitude of the Ministry of Health has been based on the premises that (I) the minimum amount of preservative should always be used, and (2) in many cases addition of chemical preservatives served as a cloak for shoddy processing in the factory. Faced by a prohibition of certain preservatives, many firms, it is said, improved their factory methods and hygiene until it was found that chemical preservation was redundant. This may have been true on occasion, but with fruit juices cases arise where there seems to be no known acceptable alternative to sulphur dioxide or benzoic acid, and it is certain that when such alternatives are discovered fruit juice processers will be quick to avail themselves of them.

As for the effect on health of the chemical additions, it is pertinent to cite the orange, black-currant and rose-hip products which are now household names throughout the country. The black-currant syrup and purée were sponsored by the Ministry of Food in $194^{\circ}$ for distribution by the Ministry's own clinics to young children; orange syrup was introduced in r94I to cover a wide age range, while the rose-hip syrup was sponsored by the Ministry of Health and the Ministry of Supply (Directorate of Medical Supplies) early in the war for general sale to priority classes (children, invalids and expectant mothers). All three products were sold with $0.035 \%$ of sulphur dioxide and, although at the inception of the black-currant and orange-syrup scheme there were some heartburnings on account of the processers' demand that sulphur dioxide should be allowed, no official evidence could be adduced to suggest that the 
preservative was dangerous. The only juice product at present in commercial production which may not contain a preservative is apple juice, and in this the Ministry of Food followed the strict letter of the German regulations.

In general, sulphur dioxide is preferred to benzoic acid; in fact, the latter material has only three points in its favour; it is tasteless, does not bleach natural colours, and is permanent. Sulphur dioxide does impart a taste (generally discernible only to a trained palate), and is volatile and easily oxidizable. But its use under carefully controlled conditions does not appreciably affect the taste of the product, it is easily and

Table 2. Loss of indophenol-reducing power in fruit syrups preserved with sulphur dioxide or benzoic acid

\begin{tabular}{|c|c|c|c|}
\hline Syrup strength & Treatment & $\begin{array}{l}\text { Condition after } \\
389 \text { days for straw- } \\
\text { berry and } 405 \text { days } \\
\text { for black currant }\end{array}$ & $\begin{array}{c}\text { Original reducing } \\
\text { power remaining } \\
\text { after storage } \\
\text { period } \\
(\%)\end{array}$ \\
\hline $50^{\circ}$ Brix & $\begin{array}{ll} & \text { Strawberry } \\
\text { Untreated } & \end{array}$ & $\begin{array}{l}\text { Fermented } \\
\text { Unfermented }\end{array}$ & $\begin{array}{l}34 \cdot 3 \\
84 \cdot 2\end{array}$ \\
\hline & $\begin{array}{l}350 \text { p.p.m. } \mathrm{SO}_{2} \text { added } \\
600 \text { p.p.m. benzoic acid added } \\
\text { Pasteurized at } 160^{\circ} \mathrm{F} \text {. for } 30 \mathrm{~min} \text {. }\end{array}$ & $\begin{array}{l}\text { Unfermented } \\
\text { Unfermented } \\
\text { Unfermented }\end{array}$ & $\begin{array}{l}8 \cdot 2 \\
45 \cdot 7 \\
40 \cdot 8\end{array}$ \\
\hline $65^{\circ}$ Brix & Untreated & Unfermented & $69 \cdot 8$ \\
\hline $50^{\circ}$ Brix & $\begin{array}{l}\text { Black currant } \\
\text { Untreated } \\
35^{\circ} \text { p.p.m. } \mathrm{SO}_{2} \text { added } \\
600 \text { p.p.m. benzoic acid added } \\
\text { Pasteurized at } \mathrm{I} 60^{\circ} \mathrm{F} \text {. for } 30 \mathrm{~min} \text {. }\end{array}$ & $\begin{array}{l}\text { Fermented } \\
\text { Unfermented } \\
\text { Unfermented } \\
\text { Unfermented }\end{array}$ & $\begin{array}{l}53 \cdot 1 \\
84 \cdot 0 \\
60 \cdot 8 \\
63 \cdot 7\end{array}$ \\
\hline $65^{\circ}$ Brix & Untreated & Unfermented & $73 \cdot 6$ \\
\hline
\end{tabular}

rapidly estimated, it quickly permeates the juice and the head-space in the container, and it is incomparably the better preservative to use where vitamin $\mathrm{C}$ retention is of importance. During the past 8 years the author has been responsible for an academic and works' investigation of this point, and there is no doubt that this advantage of sulphur dioxide outweighs the disadvantages mentioned, by implication, above.

As an example, taken from published work, however, the studies of Sills (1939) from the author's laboratory at the University of Bristol Agricultural Research Station at Long Ashton may be cited. Table 2 has been abstracted from the fuller tables given by Sills.

The use of benzoic acid in fruit syrups with high vitamin content is now seldom adopted, and processing methods have so improved since Sills's paper was written that the losses of ascorbic acid with sulphur dioxide as a preservative from the original preparation of the syrups to their sale to the consumer, say 6-12 months later, do not exceed $5-10 \%$, nor does the syrup lose any potency during the 14 days after it is opened.

The effect of head-space and, in the reverse sense, of thorough de-aeration of the syrup on retention of ascorbic acid in black-currant syrup has been investigated by Pollard, Kieser \& Bryan (1946). Comparison was made between a syrup de-aerated before bottling and a series of three syrups not de-aerated. All four products were 
preserved with sulphur dioxide $(0.035 \%)$ and filled with varying head-spaces. Table 3 summarizes the results:

Table 3. Percentage retention of ascorbic acid in black-currant syrups on storage

\begin{tabular}{llccc}
\multicolumn{1}{c}{ Type of syrup } & $\begin{array}{l}\text { Initial } \\
\text { value }\end{array}$ & $\begin{array}{c}\text { After } \\
5 \text { months }\end{array}$ & $\begin{array}{c}\text { After } \\
9 \text { months }\end{array}$ & $\begin{array}{c}\text { After } \\
\text { 18 months }\end{array}$ \\
De-aerated & $100 \cdot 0$ & $98 \cdot 1$ & $89 \cdot 0$ & $78 \cdot 6$ \\
Normal, no head-space & $100 \cdot 0$ & $96 \cdot 1$ & $91 \cdot 0$ & $74 \cdot 9$ \\
Normal, small head-space & $100 \cdot 0$ & $92 \cdot 6$ & $88 \cdot 4$ & $72 \cdot 5$ \\
Normal, large head-space & $100 \cdot 0$ & $68 \cdot 2$ & $59 \cdot 9$ & $27 \cdot 3$
\end{tabular}

The final requirements for preservation of ascorbic acid in fruit products are as follows: (I) immediate inactivation of enzyme systems in the fruit at the commencement of processing; (2) de-aeration where possible; (3) avoidance of contact with air at every stage of manufacture; (4) avoidance of contact of fruit or juice with copper, because of its catalytic effect on oxidation; (5) efficient pasteurization and filling of bottles under aseptic and anaerobic conditions; (6) use of sulphur dioxide if chemical preservative is necessary (i.e. for syrups).

The effect of sulphur dioxide varies with the sugar content of the product being preserved. During the war citrus juices were imported almost entirely in a concentrated form, and the amounts of sulphur dioxide needed to preserve the straight juices often proved insufficient for the concentrated products. It is presumed by Downer (I943) that this is 'due to the proportionally higher concentration of sulphurous acid-fixing substances, presumably chiefly glucose' in the concentrates. The Food and Drugs Act does not differentiate between free and fixed sulphur dioxide, but is concerned merely with total sulphur dioxide. Thus in syrups and concentrates the free sulphur dioxide, which has for many years been regarded as the active yeastinhibiting agent, is often reduced to a figure of 100 p.p.m., which represents a loss of $25^{\circ}$ p.p.m. which has become fixed. The process of fixation is relatively rapid, often taking only $3-5$ days to attain its maximum effect. The degree of fixation is relatively low in juices, and the same proportion of sulphur dioxide will exert a more powerful effect in a juice than in a concentrate or syrup.

\section{REFERENCES}

Baker, L. C. (1947). Brit. F. Nutrit. 1, 258.

Boyd, J. M. \& Peterson, G. T. (1945). Industr. Engng Chem. (Industr. ed.), 37, 370.

Downer, A. W. E. (1943). F. Soc. chem. Ind., Lond., 62, I 24 T.

Kertesz, Z. I. (1938). Food Res. 3, 48 r.

Money, R. W. (1947). Brit. F. Nutrit. 1, 253.

Nelson, E. K. \& Mottern, H. H. (1933). Industr. Engng Chem. (Industr. ed.), 25, 216.

Pollard, A., Kieser, M. E. \& Bryan, J. (1946). Chem. \& Ind. p. 402.

Sills, V. E. (1939). Annu. Rep. Long Ashton Res. Sta. p. I27.

Tressler, D. K. \& Curran, K. (1938). F. Home Econ. 30, 487.

Vitamin Division, Hoffman-La Roche Inc., New Jersey, U.S.A. (1946). Processing Frozen Fruit with l-Ascorbic Acid (vitamin C). 